The Geneva Papers on Risk and Insurance, 23 (No. 87, April 1998), 210-223

\title{
Insuring Litigation Risk: Some Recent Developments in England and Wales*
}

\author{
by Neil Rickman** and Paul Fenn***
}

\section{Introduction}

Each year, several million legal proceedings are commenced in England and Wales, seeking for example the enforcement of contract terms, compensation for physical injury or the dissolution of a marriage. Research over the past twenty years has revealed that such actions can be costly for individuals, with the accumulated legal fees, expert witness expenses and procedural costs often outweighing the value of the stakes recovered (see Harris et al., 1984; Civil Justice Review, 1986; Woolf, 1996). Not only can litigation be costly, the level of these costs can also be highly uncertain, not least because the rules of civil procedure in England and Wales make defeated litigants responsible for some or all of their successful opponents' costs.

The issue of insurance against litigation expense has microeconomic significance because some potential litigants may be deterred from bringing or defending their cases if they fear that costs will be too high. The Pearson (1978) Royal Commission on Civil Liability and Compensation for Personal Injury and Harris, et al. (1984) both cite evidence of this effect, particularly amongst litigants who drop their cases. Such behaviour has equity and efficiency implications since judicial enforcement of property rights ensures that those who suffer "harm" are compensated while those who cause it are forced to

* This paper was originally prepared for the joint meeting of the Geneva Association and the European Association of Law and Economics, Hamburg, April 7-8, 1997. We are grateful for participants for valuable comments. We are also grateful to the Oxford Centre for Medical Risk Studies for making data available to us. Remaining errors are ours.

** Department of Economics, University of Surrey, Guildford GU2 5XH, UK. Tel: 01483 259380; Fax: 01483259548

*** School of Management and Finance, University of Nottingham, Nottingham NG7 2RD, UK. 
internalise the costs of their actions, thereby encouraging them to invest in taking "care". It is therefore important that mechanisms exist to help individuals defray potential litigation costs. Several such mechanisms are now in place in England and Wales. To begin with, the state has traditionally provided assistance through legal aid to those who are eligible; secondly, recent reforms introduced in the Courts and Legal Services Act (1990) have permitted litigation financed through conditional fee arrangements, thereby allowing litigants to shift risk partially onto their lawyers by making the latter's fees conditional upon winning the case; finally, legal expenses insurance (LEI) policies are available from private insurers, either as standalone policies or as tie-ins with other insurance products. However, each of these mechanisms is designed to defray the litigant's own costs, not those of his opponent. Hence, given the "English" rule for the allocation of costs, some means is needed to deal with this source of uncertainty. In the case of legal aid, this has been achieved through the simple expedient of changing the rule of allocation by statute if a legally aided litigant loses his case, it is difficult for his opponent to recover costs. By contrast, this expedient is not available for cases financed through conditional fees or legal expenses insurance, and this factor has come to be seen as a key barrier to the movement away from publicly provided legal aid towards these private alternatives. Indeed, several authors have recently suggested that a principal reason for the relative maturity of the German LEI market is the fact that recoverable costs are strictly regulated in order to minimise the uncertainty under a "loser pays" cost rule (Leipold, 1995; Association of British Insurers, 1997; Prais, 1995; Rickman and Gray, 1995).

This paper therefore has three aims. First, it seeks to illustrate the extent of inter partes costs for unaided litigants cost risk in English litigation by presenting figures from a new data. These figures involve cases brought against NHS hospital trusts by patients (in medical negligence claims) or visitors/staff in other personal injury claims. This is followed by a review of several recent proposals for reform of civil procedure. These are the proposals in Woolf (1996) and the recent introduction of conditional fees. Lord Woolf produces separate proposals for general personal injury cases and for medical malpractice. We focus on the former, recognising that our dataset include a percentage of these more general cases and also that the proposals for medical negligence (Woolf, 1996, ch. 15) are, in many ways, similar in spirit to those we consider. Finally, the paper examines the potential impact of these proposals on the future of LEI in Britain, bearing in mind that Lord Woolf's proposals are currently under review pending a decision on their implementation.

The paper is structured as follows. The next section provides some information on the costs and risks involved in unaided litigation. Section 3 then describes the market for legal expenses insurance in England and Wales. Following this, we assess the implications for the market of recent policy proposals for control over costs and delays in civil litigation (Woolf, 1996). A final section concludes.

\section{Litigation costs in Britain}

An individual involved in litigation will generally have to meet two categories of legal expenses: legal fees and disbursements. The former are the fees paid by clients to their lawyers in return for work done on a case. Traditionally in Britain these have been paid on an hourly basis although. Disbursements are the expenses incurred in preparing, 
negotiating and possibly trying a case. They involve the cost of expert witnesses, of producing documents during discovery, or responding to requests and claims made by the other side, etc.

The sum total of these fees and disbursements will often be highly unpredictable to the individual, usually inexperienced, litigant. To begin with, the decision to incur cost will usually be taken by the lawyer, or on the lawyer's advice. Further, a number of these costs can be influenced by the opponent's strategic behaviour e.g. interlocutories allow one party to apply to the court for costly action on the part of the other party). Third, the English rule of cost allocation (the indemnity rule) generally makes the losing party responsible for the winner's costs ${ }^{1}$. Finally, of course, individuals rarely know in advance when their activities will lead to a legal case (not least because this will often be a function of the actions of others as well).

We can summarise these sources of uncertainty by looking at the ex ante expected cost of being involved in a legal case, $\mathrm{E}(\mathrm{c})$ :

$$
E(c)=r(1-q)\left[c^{\mathrm{p}}+c^{\mathrm{d}}+w\left(k^{\mathrm{p}}+k^{\mathrm{d}}\right)\right]
$$

Here, $r$ is the probability of being involved in a case (say, the probability of having an accident), $q$ is the probability of losing the case and $w$ is the probability that the case goes to trial rather than settles. The plaintiff's $(p)$ and defendant's $(d)$ costs of negotiating a settlement are $\mathrm{c}^{\mathrm{i}}, \mathrm{i}=p, d$ while, should these negotiations fail to resolve the case, their respective marginal costs of trial are $\mathrm{k}^{\mathrm{i}}, \mathrm{i}=p, d .{ }^{2}$ Both these sets of costs are random variables, unpredictable in advance for most individual litigants. If we denote the likely settlement amount by $S$ and the likely trial judgement by $J$ then the ex ante expected value of a case, $E(v)$, is given by

$$
E(v)=r q[(1-w) S+w J]-E(c)
$$

Equation (2) represents the nature of the gamble entered into by litigants. Given their probable ignorance of legal procedure, the price of legal services and the legal strength of their case - and possibly of their opponent - (all of which determine the values of $r, q, w, c^{\mathrm{i}}, k^{\mathrm{i}}, S$ and $J$ ), it is clear that this gamble can be a significant deterrent to risk averse individuals considering the possibility of bringing or defending a case. Such observations have prompted Lord Woolf to remark that our present system of litigation is "too uncertain: the difficulty of forecasting what litigation will cost and how long it will last induces a fear of the unknown ..." (Woolf, 1996, p. 2).

A variety of studies have looked at the costs of litigation in England and Wales in recent years. The most recent such study is in Woolf (1996, Annex III). This looked at the costs incurred by successful litigants in 2,184 cases which had started in the High Court in London between 1990 and 1995. Using High Court cases means that the cases were expensive, an observation compounded by the fact that the data were drawn from taxed

\footnotetext{
1 Theoretical, experimental and empirical literature concerning the English cost rule's effects on litigation is surveyed in Rickman (1995).

${ }^{2}$ Equation (1) makes the simplifying assumption that the loser pays all of the winner's costs. In practice, courts will reach a decision as to which costs have been reasonably incurred and will order the loser to pay these.
} 
cases - those appealed against by the party required to pay them. Thus, we can take these results as an upper-bound on costs incurred by one litigant. The study found that, across a range of civil case categories (medical negligence, personal injury, etc.), the winner's costs alone were a substantial fraction of damages recovered. For cases worth up to $£ 12,500$, these costs averaged $141 \%$ of damages, a figure which reflects the substantial fixed costs of case preparation. As the value of damages increased, costs took up a smaller percentage but, for cases worth up to $£ 100,000$, the winner's costs accounted for at least one quarter of damages awarded. These figures accord with those of earlier studies. Swanson's (1988) sample of taxed High Court cases found costs to be $52 \%$ of damages on average, while the Government's Civil Justice Review (1986) found that the value of this percentage fell as damages rose ${ }^{3}$.

Other studies attempt to overcome some of the biases in Woolf (1996) by examining data from cases which have settled as well as others that have gone to trial. Such studies are rare, however, because of their specific data requirements. In particular, because no independent register of case settlements is kept, it is necessary to negotiate access to case files (which are confidential) or to sample randomly amongst the population before following up on those individuals engaged in or embarking upon litigation. For the purpose of this paper, in order to obtain a more representative picture of the costs faced by prospective unaided litigants in hospital-related personal injury cases in England and Wales, we utilise a dataset which follows up to completion all claims opened against a particular group of defendants.

Our data are drawn from a number of English health care providers ("NHS Trusts") who have contributed to a database of both clinical negligence and employee claims which is updated regularly. We have access to 1,634 completed claims over the period 1974 to 1995. A rich variety of case-specific information is recorded for each claim, including the dates for the initiation, exchange of evidence, settlement, or abandonment of the claim; and the defence costs incurred and damages paid (if any). In addition, each new claim is initially allocated by the claims manager an estimate of its likely value if it were settled in favour of the plaintiff, and an estimate of the likelihood that the plaintiff would prevail in court; these estimates are also recorded in the database.

Figure 1 shows the ultimate litigation costs incurred and payments made for all those claims closed during the period 1990 to 1995 . For the purposes of analysis, claims have been categorised by estimated value into small (less than $£ 3,000$ ), medium (between $£ 3,000$ and $£ 10,000$ ), and large (over $£ 10,000$ ). Clearly, the larger the valuation, the higher the ultimate cost to the defendant. Moreover, the proportion of the overall cost which is represented by litigation costs is greatest for the low value cases and least for the high value cases. We focus here on the cases which are valued between $£ 3,000$ and $£ 10,000$, as these are the type of general personal injury case for which the increased control we describe below is currently being proposed in England and Wales ${ }^{4}$. Figure 2 shows how the

\footnotetext{
${ }^{3}$ In the Civil Justice Review's sample, cases were taken from the County Court, the District Court and the High Court, which respectively hear cases of ascending value. Costs were found, respectively, to be $84 \%, 32 \%$ and $36 \%$ of damages.

${ }^{4}$ As we have noted above, separate but similar, proposals have been forwarded for medical negligence cases (Woolf, 1996, ch. 15). Also, of course, a percentage of our sample is non-medical negligence personal injury cases.
} 
Figure 1: Litigation costs and payments made

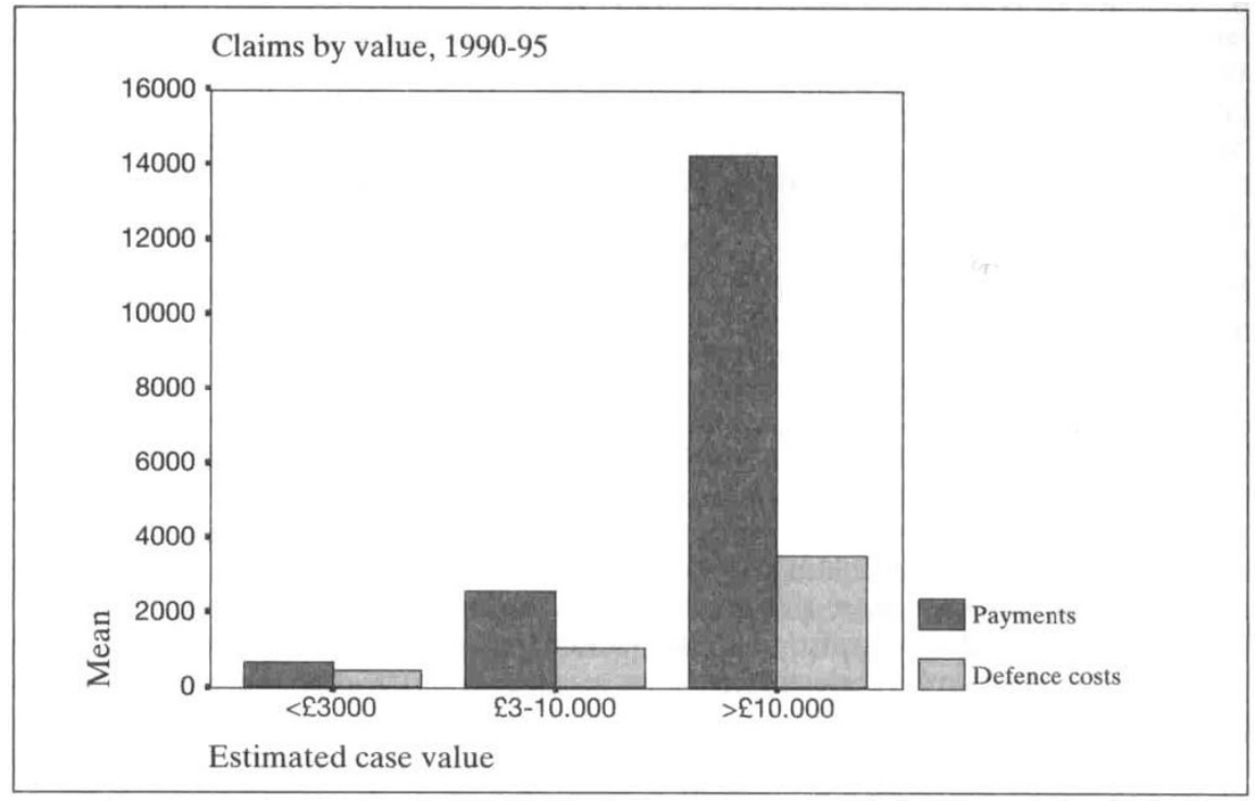

Figure 2: Distribution of litigation costs

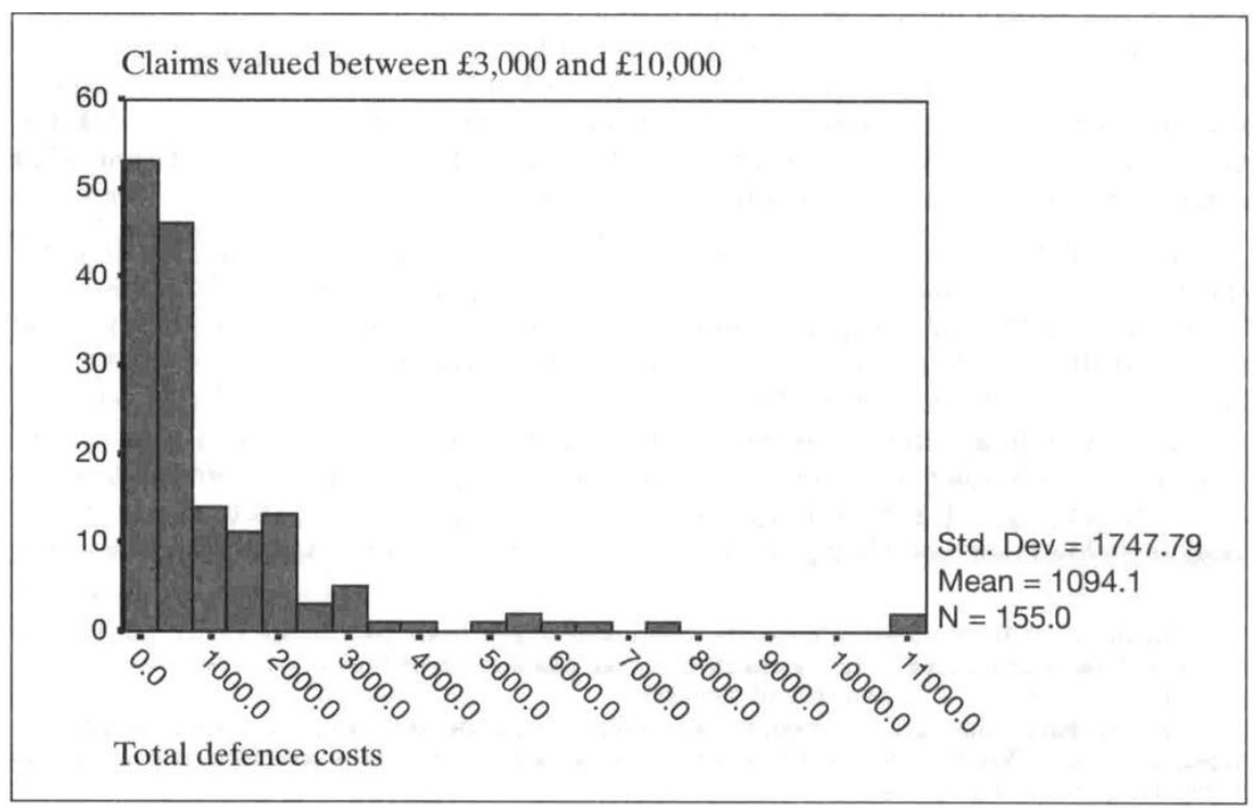


total defence costs are distributed for these cases. The mean defence cost was $£ 1,094$ (which compares with a mean payment to plaintiffs of just under $£ 3,000$ for these cases), but there is wide dispersion around that mean, with a standard deviation of $£ 1,747$. The uncertainty in defence costs represented in this Figure mirrors exactly the uncertainty faced by an unaided plaintiff who is unsure about liability5.

Figure 3: Delay from claim to first disclosure

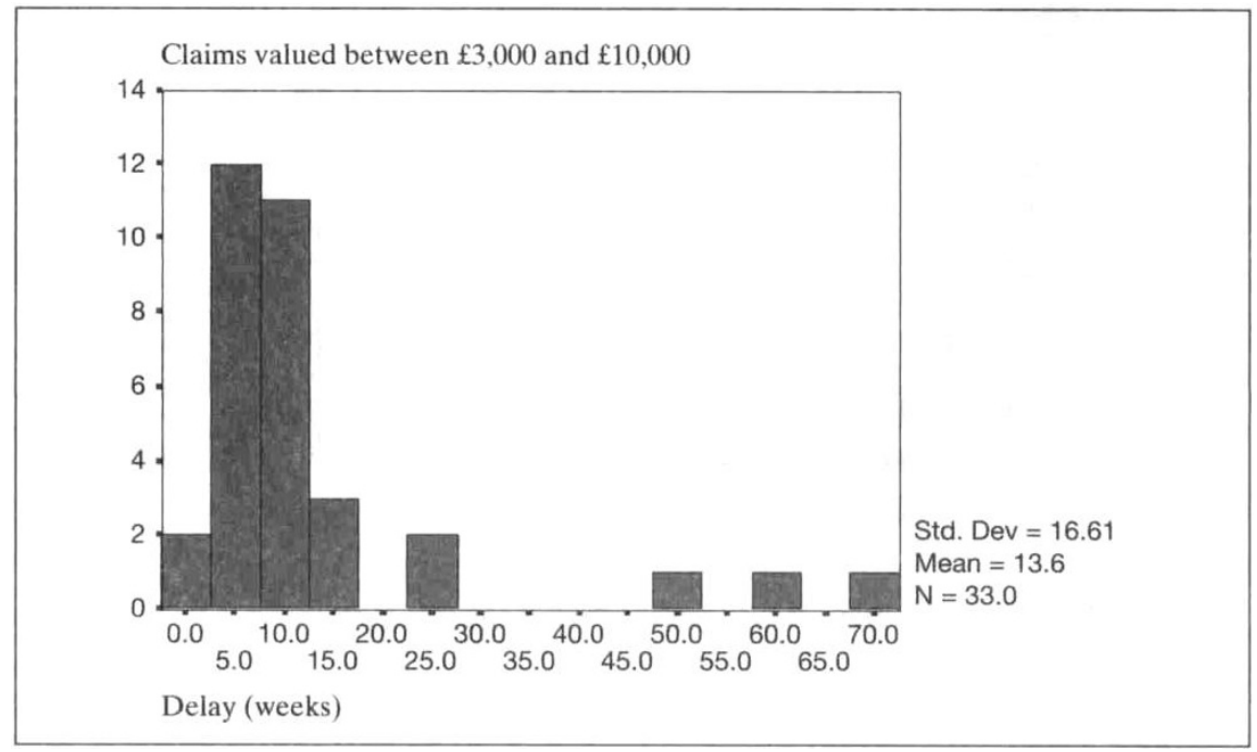

Figures 3 to 6 show how this uncertainty over costs is related to the staging of the litigation process. After the initiation of a claim (which is often dated from the first receipt of a letter stating the intention to pursue a legal claim), the parties then exchange evidence in the form of disclosure by the defendants and witness statements by the plaintiffs (Figures 3 and 4). This takes place on average some 3-4 months after the claim is initiated, although a relatively small number of cases take much longer. By contrast, the timing of the receipt by the defendant of an expert's report from the plaintiff (in the relatively few cases where such reports are compiled) can take much longer and is subject to much more variation (Figure 5). Clearly, there is a tendency for the collection of evidence in preparation of a case to be spun out in some cases after the initial exchange of information. Consequently, the delay from initiation to settlement or closure of cases (Figure 6) is subject to a significant amount of uncertainty as a consequence of bargaining behaviour by both parties, each of whom are in possession of private information which they may choose to withhold or release according to strategic advantage.

${ }^{5}$ In our sample of defendants, $60 \%$ felt that they were definitely or probably not liable, and $13 \%$ felt that liability was uncertain. If plaintiffs shared these beliefs, $73 \%$ would feel a significant threat of bearing their opponents costs. 
Figure 4: Delay from claim to first receipt of witness statement

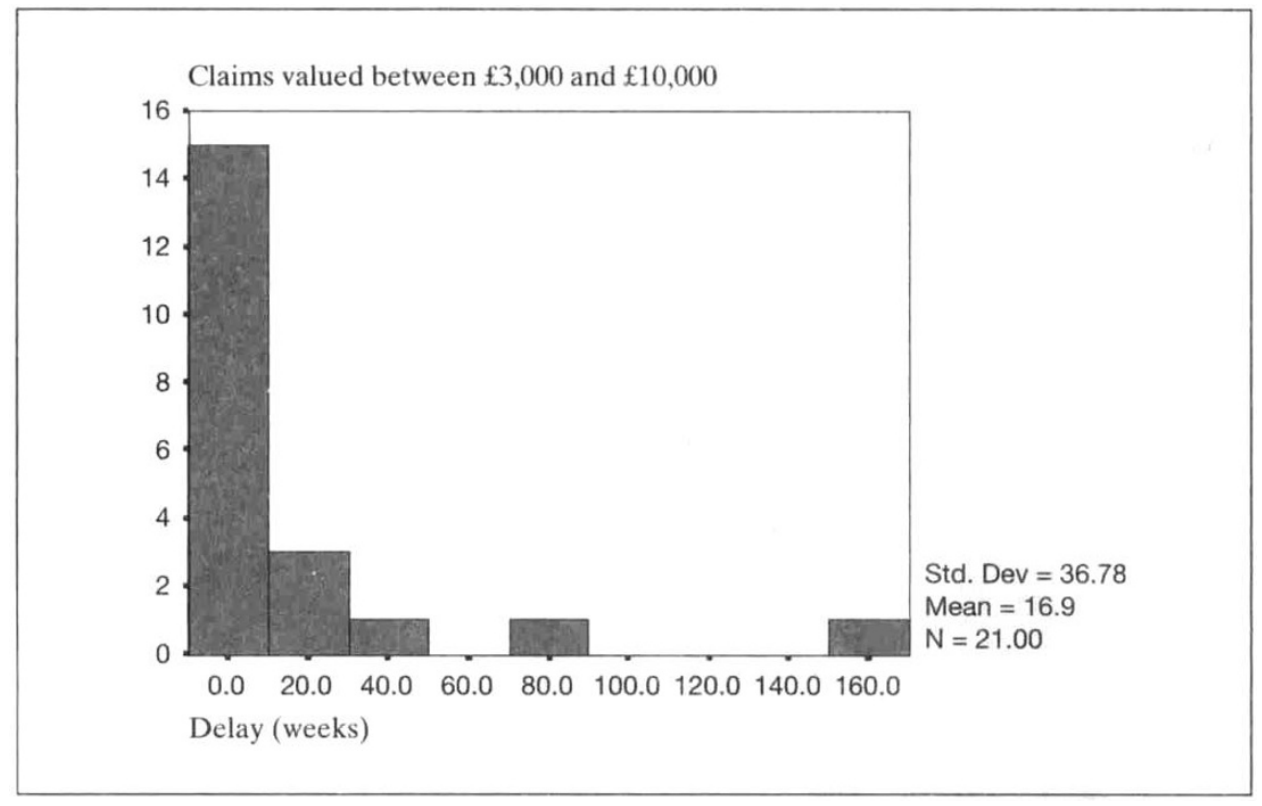

Figure 5: Delay from claim to first receipt of expert report

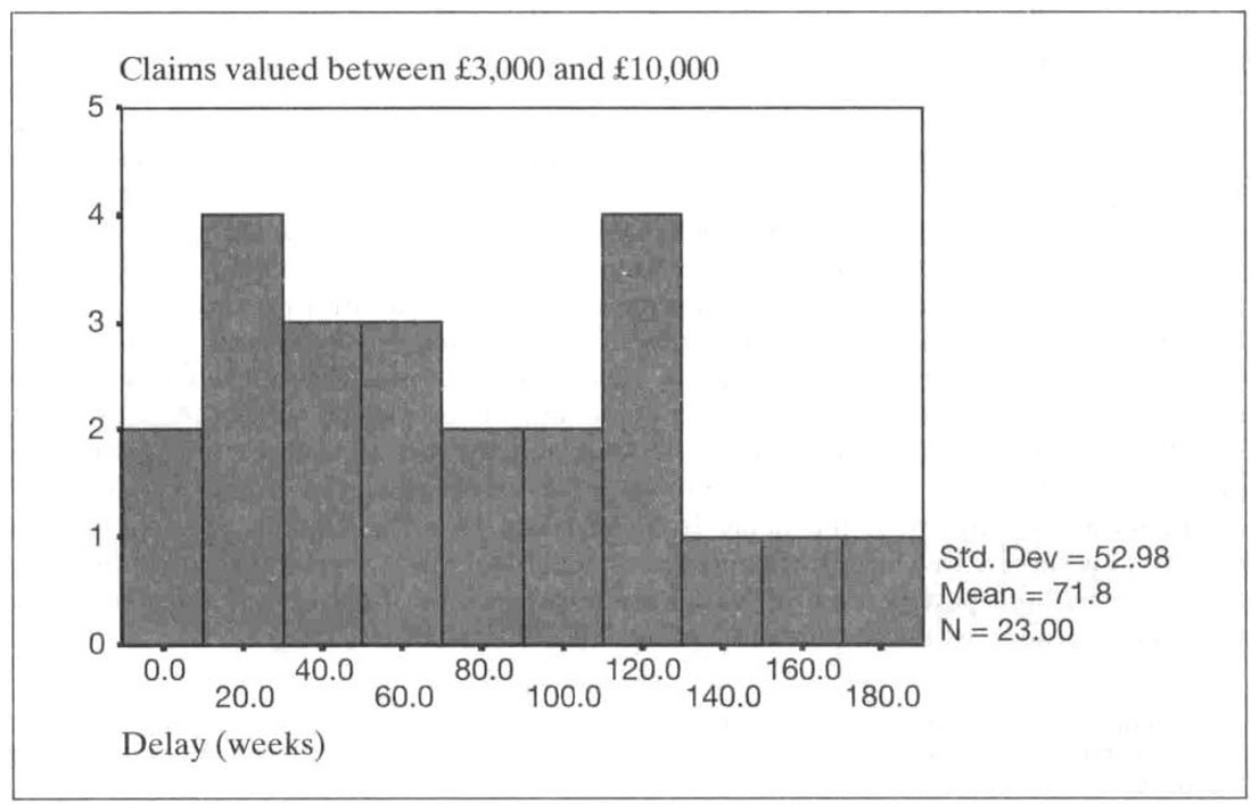




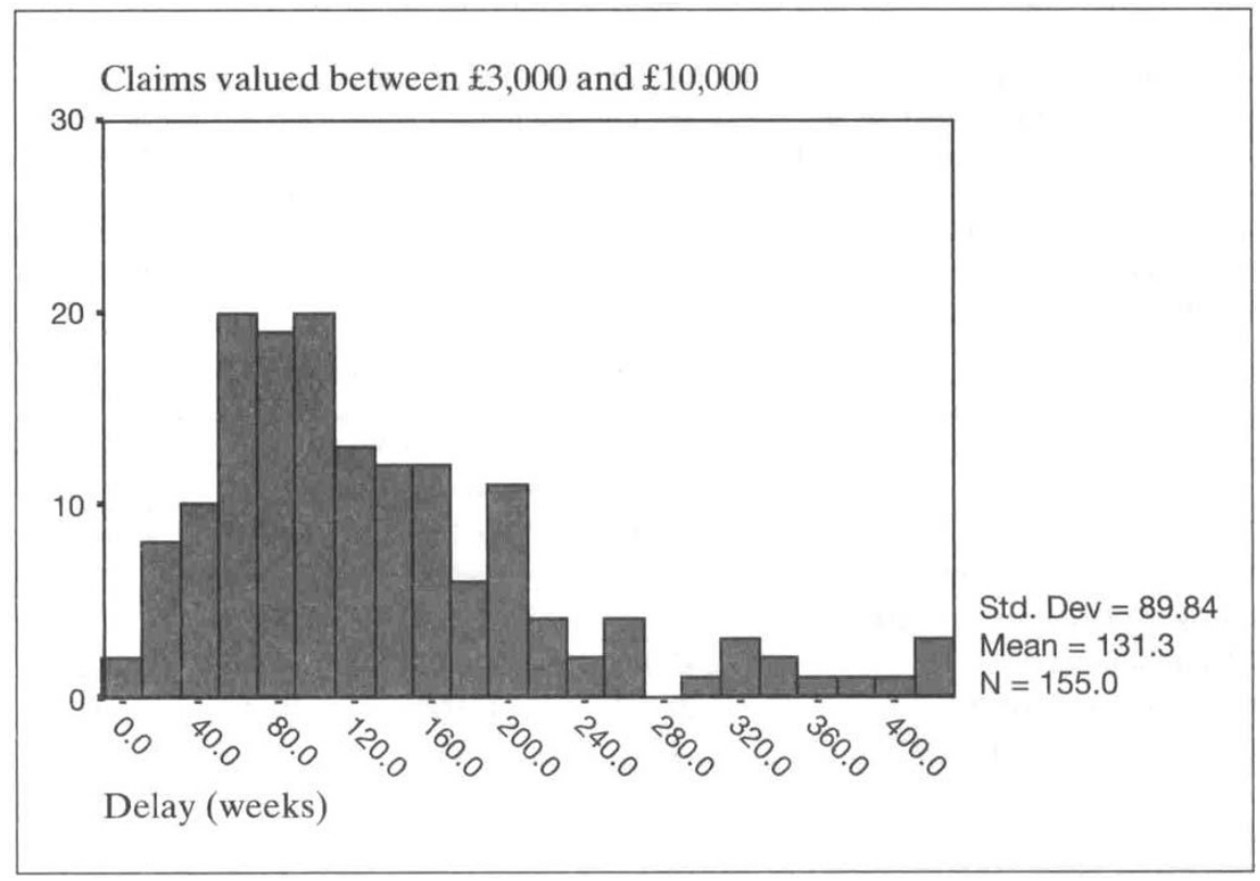

\section{Legal expenses insurance in Britain}

Prior to the late 1960s, legal prohibitions prevented legal expenses insurance from being available in Britain. In particular, only when the Criminal Law Act of 1967 abolished the common law offences of champerty and maintenance did it become possible for third parties to assist in funding litigation. Thus, unlike the jurisdictions of France, where LEI first originated in 1885, and Germany, where policies appeared in 1925, LEI has only been available in Britain since 1974.

It is difficult to gain a quantitative impression of the market in its early years: no published data are available. However, it is generally acknowledged that growth in the market was slow. For example, Prais (1995, p. 433) refers to the "chequered history" of LEI in Britain, while Downing (1995, p. 16) describes these early years as ones of "quiet stagnation". The mid-eighties saw the market grow "significantly" (Association of British Insurers, 1997, p. 10) before a period of losses in 1990-91 checked this progress.

Data for the 1990s are more readily available. These divide the LEI market into three basic products: Motor (ULR), Non-Motor (Personal) and Non-Motor (Commercial). The first of these refers to uninsured loss recovery (ULR) policies, which cover motorists against pursuing accident losses not covered by their compulsory motor insurance. Such policies are not required by holders of fully comprehensive motor insurance, which covers 
such losses automatically6. Personal policies cover legal expenses incurred in, for example, some family disputes, home and employment matters (including personal injury cases). Commercial policies offer legal expenses cover to businesses for, inter alia, contract and employment disputes. Policies can be further sub-divided into stand-alone and add-on policies: the former refer to self-contained policies bought specifically to insure against legal expenses risk in a variety of circumstances, the latter are bought in conjunction with other policies (for example, ULR policies can be bought in conjunction with general motor insurance). Finally, policies can also be divided into before-the-event and after-the-event types; the former being purchased before the insured event has occurred, the latter being purchased to cover legal expenses once a case has started (see below).

Table 1: Structure of LE1 Market in Britain, 1995

\begin{tabular}{lrrrr}
\hline & Motor (ULR) & \multicolumn{2}{c}{ Non-Motor } & Total \\
\hline & & (Personal) & (Commercial) \\
Number of policies & $8,297,014$ & $3,798,753$ & 244,858 & $12,340,625$ \\
Gross premiums written (£000) & 52,668 & 25,571 & 19,538 & 97,777 \\
Gross premiums earned (£000) & 48,730 & 23,193 & 18,025 & 89,948 \\
Claims notified & 343,823 & 11,583 & 5,997 & 361,403 \\
Claims incurred (£000) & 20,788 & 12,009 & 10,500 & 43,297 \\
Claim rate (claims per 1000) & 41.44 & 3.05 & 24.49 & 29.29 \\
Average premium(£) & 5.87 & 6.11 & 73.61 & 7.29 \\
Average claim (£) & 60.46 & 1036.78 & 1750.88 & 119.8 \\
\hline
\end{tabular}

Source: Association of British Insurers.

Table 1 shows the relative importance of ULR, Personal and Commercial policies in 1995, the latest year for which data are available. The number of policies sold in 1995 was 12.3 million. ULR accounted for $67 \%$ of these, Personal policies for $31 \%$ and Commercial policies for just $2 \%$. These policies generated $£ 90$ million in gross premium income, with just over half of this coming from ULR business. The relatively low volume of commercial policies generated $£ 18$ million, almost as much as generated by personal non-motor policies. This, of course, reflected the higher premiums charged on Commercial policies ( $£ 71.10$ on average compared with an overall average of $£ 6.10$ per annum) which, in turn, reflected the relatively high claim rate on Commercial policies and the high average claim per policy. By contrast, ULR claims, which are mainly for the recovery of policy excesses, were more frequent but of relatively low value.

To gain an impression of the market's development in the 1990s, Figure 7 shows the number of policies sold during the period. LEI has exhibited overall growth from 1990 to 1995: policy numbers rose in total from 10 million to 12.3 million, reaching a peak in 1992 (13.6 million). This peak was fuelled mainly by Non-Motor (Personal) and ULR policies. As the number of personal non-motor policies dropped a year later, so did the total.

${ }^{6}$ Thus, in the short run, an upper limit on the ULR market exists, currently around 7 million vehicles in Britain (Association of British Insurers, 1997, p. 11). 
Figure 7: LEI in Britain, 1990-95

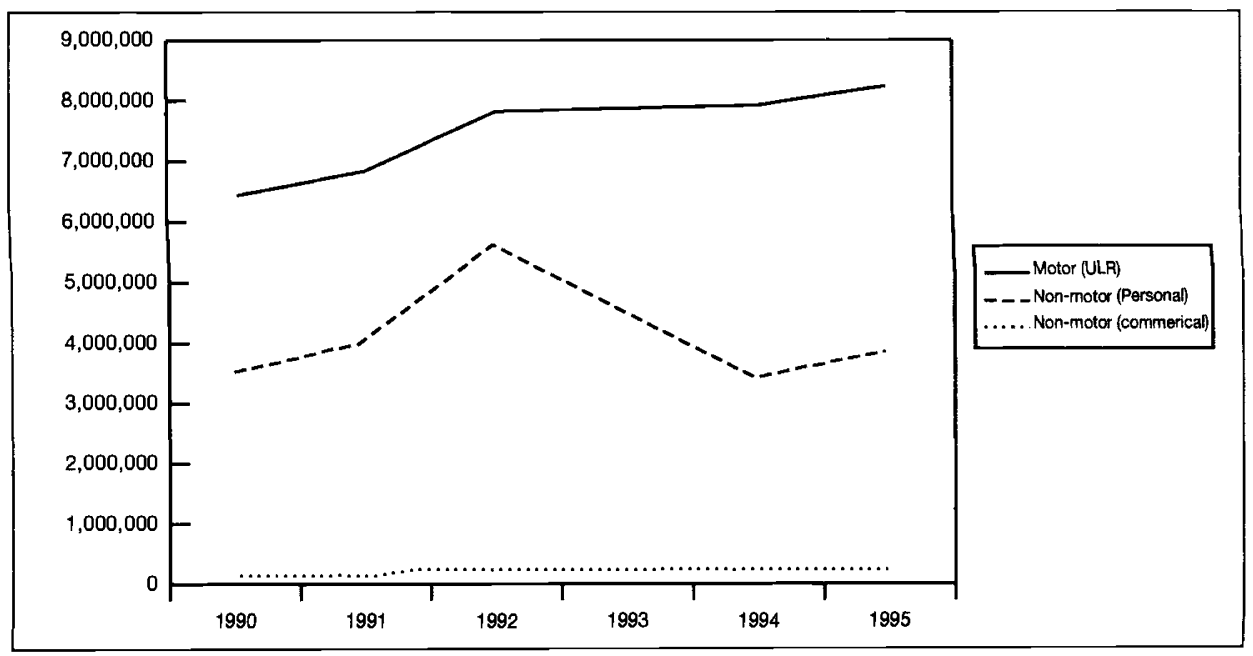

Source: Association of British Insurers.

Although, when compared with the reports of earlier LEI activity, these data suggest a relatively buoyant market, three observations should be borne in mind. The first is that the market is still comparatively small. For example, the Association of British Insurers (1997) estimates that 101 million long-term insurance policies were sold in 1995, generating premium income of around $£ 20$ billion. Alternatively, in $1993 / 4$ the State spent $£ 1.2$ billion on 3.5 million acts of assistance under the legal aid scheme. Of this, $£ 544$ million was spent on civil legal aid, which most closely approximates the types of case funded by LEI, and covered approximately 400,000 acts of assistance ${ }^{7}$. This compares with a similar number of notified LEI claims $(360,000)$ but significantly less expenditure on premiums ( $£ 84$ million). Thus, the State's expenditure on comparable third party legal expense cover (for those who are eligible) is considerably larger than private provision, though assisting in a similar number of cases. The second observation to make about the LEI market in the 1990s is that it has witnessed considerable competitive activity over the period. This has mainly taken place in the ULR market where new entrants have competed down premiums to levels that some have argued are unsustainable (see Lang, 1996, p. 5). Coupled with this has been a concern, particularly in the early 1990s, that inadequate regulation allowed brokers to enter without sufficient insurance backing. The result was losses in the 1990-91 recession and several small players exiting in 1995, when ULR claims rose from 367,000 to 452,000 (an increase of $23 \%)^{8}$. The point is that, although the 1990 s have brought LEI growth, there is uncertainty about whether this has led to excess capacity in ULR, implying that the growth may not be sustainable. The final observation about the current LEI market in Britain is that it is still heavily dominated by ULR. Thus, between 1990 and 1995, ULR accounted for

${ }^{7}$ We are excluding Green Form advice from the definition of civil legal aid here. This might be more appropriately compared with the LEI helplines.

8 A self-regulatory body, the Motoring Uninsured Loss Recovery Association, has since been established. 
$63 \%$ of policies sold, $55 \%$ of gross premium income and $94 \%$ of claims notified. To the extent that such policies are purchased as add-ons to motor insurance policies, it is not clear whether growth in ULR implies a thriving LEI market as a whole ${ }^{9}$. This is particularly important given that legal aid, which might be tightened under proposed reforms, covers a multitude of family and personal cases. Thus, when considering whether the private market for LEI can respond to these proposals, we must ask why the market for consumer and household legal expenses has remained "virtually untapped" (Downing, 1995, p. 16), and whether this will continue to be true in the future ${ }^{10}$.

\section{Policy reforms and the future of legal expenses insurance}

Several policy measures could help to stimulate the private market for LEI. These would involve more cost certainty on the supply side, along with measures to raise awareness of legal costs on the demand side. With this in mind, it is interesting to consider recent proposals aimed at reforming aspects of legal service provision in England and Wales. These are Lord Woolf's recent proposals for improving access to civil justice (Woolf, 1996), and the introduction of conditional fees in 1990 (finally implemented in 1995). Although neither of these explicitly aims to encourage LEI, each involves measures which would help reduce the insurer's uncertainty over inter partes costs ${ }^{11}$.

Lord Woolf has recently completed a two year review of the civil justice system (Woolf, 1996) and his proposals are currently being considered for implementation by the new British government. The result is an extensive package of reform proposals (303 in total) aimed at tackling the "key problems facing civil justice today" (Woolf, 1995, p.7): cost, delay and uncertainty. Many of Lord Woolf's proposals have potential implications for the LEI market. In general, he envisages a system where the timescale of litigation is more certain, litigation is less complex and costs are more predictable. The mechanisms for achieving this include active case management by court officials, precise protocols for the conduct of a case and, in circumstances to be described below, limits on the use of what are currently perceived as strategic devices for increasing cost and delay. It should be clear from our earlier discussion how a system of litigation with this "landscape" might reduce the LEI market failures due to cost and process uncertainty. We focus specifically on the proposed cost reforms.

Lord Woolf proposes that litigation be divided into three categories: small claims, fast-track and multi-track. The first of these already exists and provides a mechanism for small claims (currently up to $£ 1,000$ ) to be heard before a court without the expense of lawyers or other potentially costly legal devices. It is proposed that the small claims jurisdiction be extended to cases of up to $£ 3,000$ in value. In this way, a host of such claims will be removed from excessive cost risk: a potentially important achievement given the nature of litigation fixed costs. Fast-track cases are those whose predicted value is below

\footnotetext{
${ }^{9}$ Indeed, since only $25 \%$ of those surveyed by Which? (1991) knew they were covered by LEI, it is unclear whether high ULR sales signals high demand for such LEI.

10 To illustrate the relatively limited nature of non-ULR supply, only twelve of the twenty-two firms offering ULR policies in Insurance Age's (1996) survey, also offered non-motor personal policies.

11 Current proposals for the reform of legal aid in England and Wales also have potential implications for the LEI market. See Lord Chancellor's Department (1996) and Bowles and Rickman (1998)
} 
$£ 10,000^{12}$. Finally, multi-track cases are those with values greater than $£ 10,000$ or involving particularly complex points of law. Most detail on costs and procedure are provided on fast-track cases.

Fast-track cases would be time-tabled to last between 20 and 30 weeks. They would provide for limited discovery of documents, limited use of expert witnesses (both often costly) and a tightly regulated trial, if necessary. Costs recoverable from the other side would be fixed, thus reducing the risk of facing a considerable costs order under the English costs rule. Maximum recoverable costs would be $£ 2,500$ plus VAT. Lord Woolf suggests a costs schedule as depicted in Figure 8. This allows for different recoverable costs depending on whether the case is standard and valued at below $£ 5,000$ (Band $A$ ), valued at $£ 5,000$ but requiring additional work or standard and valued up to $£ 10,000$ (Band $B$ ) or valued up to $£ 10,000$ but requiring additional work $(C)$. Recoverable costs would also vary with the stage reached when the case ended. For example, in Figure 8, if Stage $s_{1}$ (all preliminary work for the case to be allocated to the fast-track) is reached, $40 \%$ of claimant costs would be payable by the losing party. If Stage $s_{2}$ (case set down for trial) is reached, $70 \%$ of costs are deemed to have been spent, thus making the parties liable for this proportion of their estimated costs. The third stage $\left(s_{3}\right)$ involves preparing for trial, and another $20 \%$ of costs become recoverable here. Finally, trial itself $\left(s_{4}\right)$ implies that the last $10 \%$ of estimated costs are recoverable. Thus, absent a specific agreement to the contrary between solicitor and client, Lord Woolf's cost regime would represent a fixed fee per stage of the case for the solicitor.

Figure 8: Recoverable Costs under Woolf (1996)

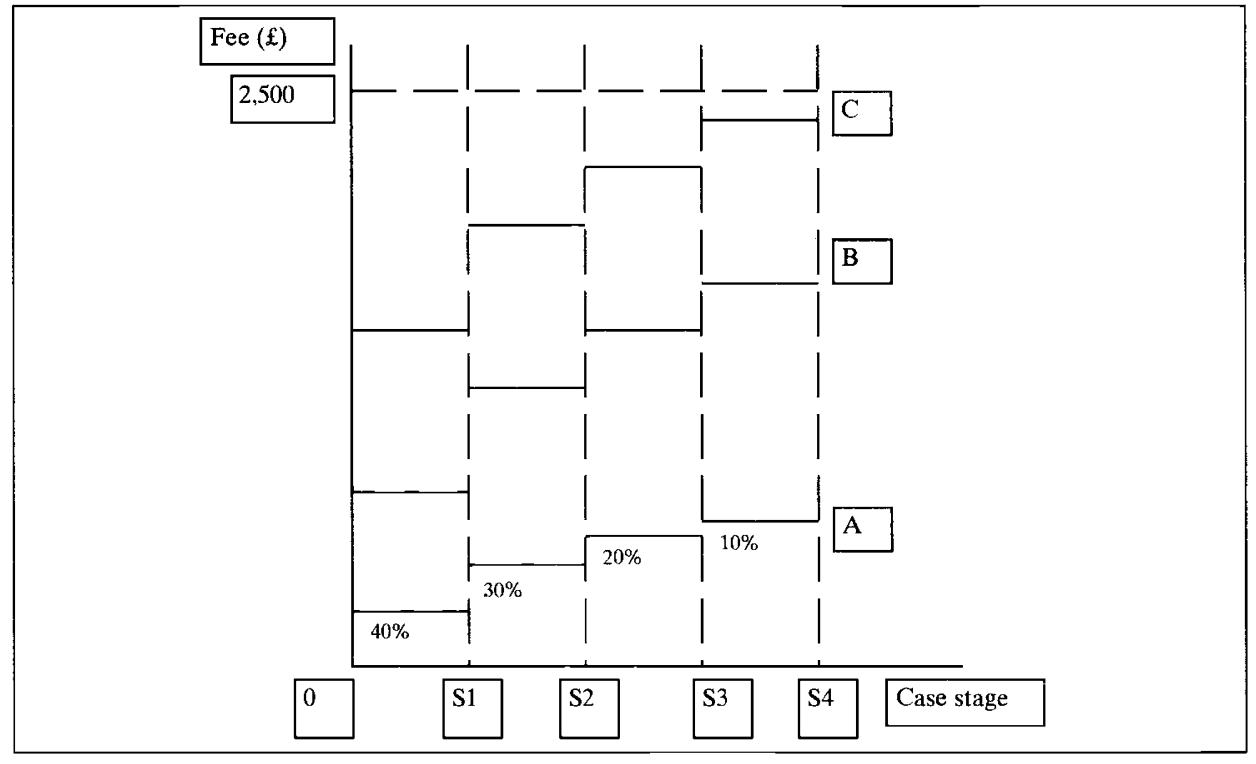

12 Thus, $42 \%$ of the cases in Woolf's costs study would qualify either for small claims or the fast track. 
This system raises several interesting incentive questions. However, for the purposes of the current paper, the main concern is the likely effect on LEI. One problem might be that these proposals could stimulate the supply-side but might remove an element of the demand-side need for LEI: capped, predictable costs makes litigation less of a gamble, even in the presence of the indemnity rule. Lord Woolf is clear that his proposals will have a positive effect on the LEI market: LEI will "only become more generally available if costs are firmly controlled in the ways that I am proposing" (Woolf, 1996, p. 10). This seems realistic: many people insure items worth less than $£ 2,500$, a sum which would only be half of the losing litigant's costs liability.

Another way in which exposure to legal costs has been changed recently is through the introduction of conditional fees (see Napier and Bawdon, 1995). As we have seen, these allow lawyers to waive their fees when a case is lost, in return for a mark-up (a risk premium) when successful. Of course, this still leaves the litigant facing disbursements and the risk of having to meet an order for inter partes costs. Because these risks are reduced by the extent of the lawyer's fee waiver, LEI firms have begun to offer innovative policies to those with a potentially actionable case. These after-the-event policies differ from normal LEI policies by being specific to a given case and their availability being conditional on an event having taken place. Clearly, the higher conditional probability of having to meet costs is compensated by the reduced need to meet own legal fees: effectively, the LEI firms and lawyers are combining to insure the litigant for a specific case. To the extent that conditional fees can be used in, say, personal injury actions which are not motor-related, such after-the-event policies could provide LEI firms with the opportunity into new consumer and household markets ${ }^{13}$. An obvious obstacle here is that after-the-event policies tend to be more expensive than before-the-event ones (at $£ 80$, they are currently about four times the price).

\section{Conclusion}

We have reviewed in this paper the way in which the prospect of paying the other party's costs in litigation imposes a significant risk for British litigants who are unsure about their likelihood of prevailing in court. The risk faced by plaintiffs who are bearing the cost of their own representation is measurable by reference to the defence costs in equivalent cases. We have presented some evidence in relation to the uncertainty surrounding the timing and scale of legal expenses for personal injury cases arising out of professional negligence and employers' liability. For plaintiffs who wish to pass on this uncertainty to legal expenses insurers, there is likely to be a significant cost in terms of a security loading on premiums. This is the basis of the suggestion that litigation cost uncertainty is a factor preventing the expansion of the LEI market in Britain. The proposed reform of the litigation process in England and Wales will, if implemented, bring the position of litigants in these countries more into line with those in Germany, where a similar rule of cost allocation is in place, but where lawyers are constrained in the extent to which they can recover costs from losing parties. It remains to be seen whether these

${ }^{13}$ In principle, because the fee size is not related to the monetary size of the case, it would be possible to apply conditional fees to non-personal injury circumstances such as family and matrimonial cases. Current policy prevents this, however. 
proposed new regulatory developments, or the newly liberated mechanisms for risk transfer through a combination of conditional fees and after-the-event insurance, is more influential in determining the future of legal expenses insurance in Britain.

\section{REFERENCES}

Association of British Insurers (1997): Insurance Trends, Issue 12 (January), 10-16, Association of British Insurers, London.

BOWLES, R. \& RICKMAN, N. (1997): “Asymmetric Information, Moral Hazard and the Insurance of Legal Expenses", Geneva Papers on Risk and Insurance, this issue.

Civil Justice Review (1986): Personal Injuries Litigation Consultation Paper, February.

DOWNING, H. (1995): “A Rocky Road”, Post Magazine, 12th January, 16-17.

HARRIS, D et al. (1984): Compensation and Support for Illness and Injury, Clarendon Press, Oxford. Insurance Age (1996): Legal Expense '96, November.

Lord Chancellor's Department (1996): Striking the Balance: The Future of Legal Aid in England and Wales, Cm 3305, HMSO, London.

LIEPOLD, D. (1995): "Limiting Costs for Better Access to Justice: The German Experience", in A. Zuckerman \& R. Cranston (eds.) Reform of Civil Procedure: Essays on "Access to Justice", 265278, OUP, Oxford.

NAPIER, M. \& BAWDON, F. (1995): Conditional Fees: A Survival Guide, Law Society, London.

PEARSON, Lord (1978): Report of the Royal Commission on Civil Liability for Personal Injury (3 vols), Cmnd 7054, HMSO, London.

PRAIS, V. (1995): "Legal Expenses Insurance", in A. Zuckerman \& R. Cranston (eds.) Reform of Civil Procedure: Essays on "Access to Justice", 431-446, OUP, Oxford.

RICKMAN, N. (1995): "The Economics of Cost-Shifting Rules", in A. Zuckerman \& R. Cranston (eds.) Reform of Civil Procedure: Essays on "Access to Justice", 327-3345, OUP, Oxford.

RICKMAN, N. \& GRAY, A. (1995): "The Role of Legal Expenses Insurance in Securing Access to the Market for Legal Services", in A. Zuckerman \& R. Cranston (eds.) Reform of Civil Procedure: Essays on "Access to Justice", 302-325, OUP, Oxford.

SWANSON, T. (1988): "Bargaining with Repeat Players: The Impact of Insurance Company Defendants Upon Tort Litigation", Discussion Paper 88-08, Department of Economics, UCL, London.

Which? Magazine (1991), "Going to Law: One Law for the Rich?", 227-230, National Consumer Council, London.

WOOLF, Lord (1995): Access to Justice: Interim Report to the Lord Chancellor on the Civil Justice System in England and Wales, HMSO, London.

WOOLF, Lord (1996): Access to Justice: Final Report to the Lord Chancellor on the Civil Justice System in England and Wales, HMSO, London. 